\title{
Pax genes and their roles in cell differentiation and development Ahmed Mansouri ${ }^{\star}$, Marc Hallonet ${ }^{\dagger}$ and Peter Gruss $\ddagger$
}

\begin{abstract}
Members of the Pax gene family are expressed in various tissues during ontogenesis. Evidence for their crucial role in morphogenesis, organogenesis, cell differentiation and oncogenesis is provided by rodent mutants and human diseases. Additionally, recent experimental in vivo and in vitro approaches have led to the identification of molecules that interact with Pax proteins.
\end{abstract}

\author{
Addresses \\ Department of Molecular Cell Biology, Max-Planck Institute for \\ Biophysical Chemistry, Am Fassberg 11, D-37077 Göttingen, \\ Germany \\ e-mail: amansou@gwdg.de \\ te-mail: mhallon@gwdg.de \\ †e-mail: pgruss@gwdg.de
}

Current Opinion in Cell Biology 1996, 8:851-857

(C) Current Biology Ltd ISSN 0955-0674

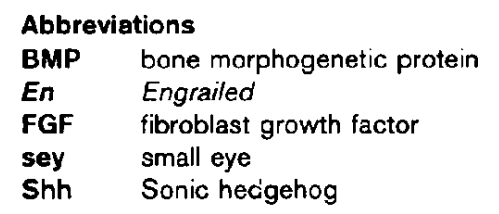

\section{Introduction}

The murine Pax gene family was identified on the basis of sequence homology with Drosophila segmentation genes [1,2] and now consists of nine members. All Pax proteins contain a paired-box, DNA-binding domain of 128 amino acids located at the amino-terminal end. This domain has been highly conserved during evolution and is found in Drosophila and in human, mouse, rat, chicken, quail and zebrafish genes. Distinct classes or subgroups of Pax genes are defined by the presence or absence of a paired-rype homeobox and of an octapeptide coding region, in addition to the paired box (see Fig. 1) [3,4]. Paired box containing proteins are transcription factors, as they display sequence-specific DNA-binding activity and can regulate transcription $[5,6]$.

Pax genes display dynamic expression patterns during ontogenesis in a large variety of tissues, and mutant phenotypes correlate very well with the expression patterns (see Fig. 2). For example, Paxl is expressed in the sclerotome and is mutated in undulated mice suffering from skeletal abnormalities [7]. Pax3 is expressed in the limb muscle, neural tube and neural crest, and is mutated in Splotch mice and human Waardenburg syndrome in which malformations of all these structures occur $[8,9]$. Pax6 is expressed during eye formation and is mutated in small eye (sey) mice and rats [10-12], and in human aniridia [13]; in all of these, eye defects are displayed. Pax2 is expressed during eye and kidney development [14] and is mutated in a human family with kidney and eye abnormalities [15]. Pax genes clearly play important roles during the formation of many structures. Furthermore, deregulated expression of $P a x$ genes may lead to oncogenesis [16-18].

In this review, we focus on recent data documenting the role of Pax genes, and the interaction of the Pax proteins with other transcription factors, in the development of the nervous system, in organogenesis and in cell proliferation and differentiation.

\section{Pax genes in the central nervous system}

The roles of Pax genes are particularly documented at the level of the nervous system, which consequently may represent a model for the study of the function of the Pax genes. All $P a x$ genes, except $P a x 1$ and $P a x P$, are expressed in various restricted territories in the neural tube. Unlike Hox genes, Pax genes are found in the more rostral domains of the brain: Pax 6 is found in the telencephalon [10,19], $\operatorname{Pax} 3$ and $\operatorname{Pax} 7$ in the mesencephalon [19-21], and Pax2, Pax5 and Pax8 at the midbrain-hindbrain boundary [19,22-24] (see Fig. 2). In the spinal cord, Pax genes display restricted expression patterns along the dorsoventral axis.

In the brain, comparison of the expression domains of forkhead, Wnt, Engrailed (En), and Pax genes with sites of neuronal differentiation suggest that some Pax proteins are morphoregulators of development of the brain $[19,25,26]$. Several Pax6 semidominant mutations are documented in the mouse, rat and human, with various phenotypic severities. At the cellular level, Pax6 mutations cause a delay in neuronal migrations in a gene-dose-dependent manner, and impair axonal growth and differentiation [27]. In mouse sey mutants, $D l x I$ gene expression, which is normally specific for the ganglionic eminence, ectopically extends into the cortex, where Paxb is normally expressed. Pax6 function is thus necessary for establishing and/or maintaining the frontier between two brain territories [28*0. Overexpression of the chicken Enl gene in medulloblastoma cell lines results in the downregulation of PAX6 expression, thus suggesting that these genes are inversely regulated [29]. In addition, grafting experiments of an Engrailed-expressing midbrain-hindbrain piece of neuroepithelium in which fibroblast growth factor (FGF) 8 is expressed onto diencephalic structures can induce the expression of $E n 2$ in the host adjacent tissues [30]. Moreover, FGF8 has been recently proposed as an organizer of this brain region and could be a major 




cture of the Pax proteins. All Pax proteins contain a paired-box, DNA-binding domain (paired domain) of 128 amino acids, located at amino-terminal ends. Distinct subgroups of proteins are defined by the presence or absence of a paired-type homeobox (HD) and of an peptide (OP) (related genes share the same patterning on the figure). In addition to the paired domain, Pax3, Pax4, Pax6 and Pax7 have cond DNA-binding domain, the paired-type homeobox (HD), at their carboxy-terminal ends. This homeobox is truncated and only carries first helix in Pax2, Pax5 and Pax8, and is totally absent in Pax1 and Pax9. In addition, all Pax proteins, except Pax4 and Pax6, carry an peptide of unknown function between the paired domain and the homeobox. Pax-related genes share overlapping expression patterns with 1 other. Although some Pax genes may be present on the same chromosome, they are not clustered, as compared with the Hox genes ih are clustered.

ulator of this cascade of regulations, which regionalizes embryonic neuroepithelium $\left[31^{\bullet \bullet}, 32\right]$.

2, $P a x 5$ and $P a x 8$ are expressed at the midbrain-hindbrain Indary level, as are members of the Wnt, Engrailed, and FGF gene families [33*•]. Injection of ancibodies ed against the zebrafish $\mathrm{Pax}[\mathrm{b}]$ protein, a homologue Pax2, Pax5 and Pax8, causes specific and localized formations at this boundary that are associated with lecrease of $W n t l$ and $E n 2$ RNA in this area [34]. lilarly, Pax5-knockout mice exhibit defects in tissues ived from the posterior midbrain region and the ral hindbrain; the inferior colliculus is partially deleted and the foliation of the cerebellum is perturbed in these mice [35]. These results, and the phenotypes observed in $W n t 1^{-1}$ and $E n 1^{-1}$ mice, in which the caudal midbrain and cerebellum are severely affected $\left[33^{\circ}\right]$, clearly indicate that $\mathrm{Pax}, \mathrm{Wnt}$ and $\mathrm{En}$ act in concert during the development of the midbrain-hindbrain boundary region.

In the developing eye, $P a x ?$ is expressed exclusively in the optic stalk, and Paxb in the eye cup [36]. That these two genes are inversely regulated is confirmed by ectopic overexpression of the ventralizing factor Sonic hedgehog (Shh) which leads to overexpression of $\mathrm{Pax2}$ 


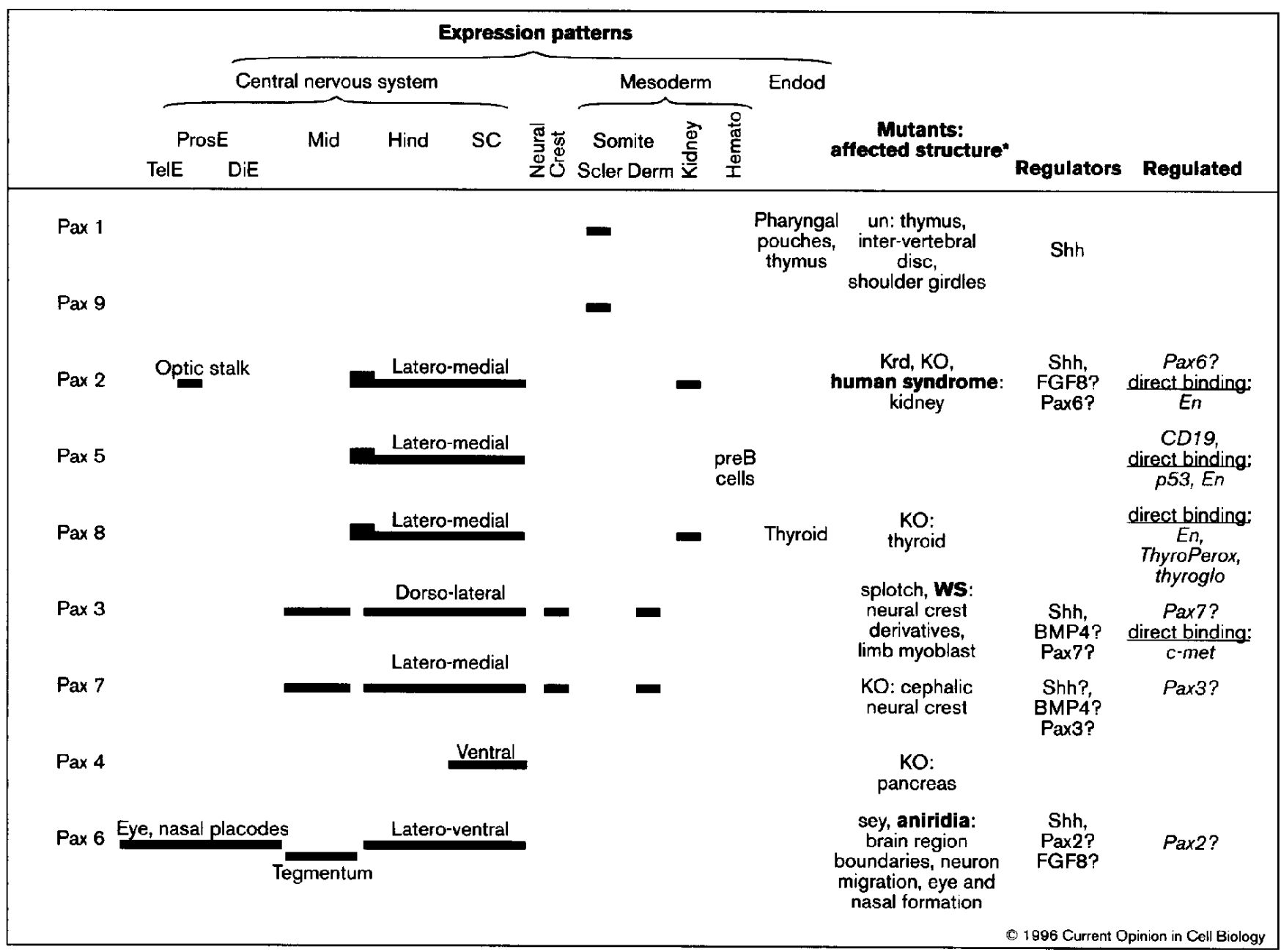

Schematic summary of the expression patterns of Pax genes, the structures affected by mutations in the Pax genes, and the molecules regulating or being regulated by the Pax proteins. The patterns of expression indicated in this table are a simplification of the complex expression patterns of the Pax genes. The thick black horizontal lines represent expression patterns of the Pax genes. The expression of Pax2, Pax5 and Pax8 is more expanded at the midbrain-hindbrain boundary. Derm, dermomyotome; DiE, diencephalon; Endod, endoderm; Mid, midbrain; Hemato, haematopoietic system; Hind, hindbrain; KO, knockout; Krd, kidney and retinal defects; ProsE, prosencephalon; Scler, sclerotome; SC, spinal cord; TelE, telencephalon; thyroglo, thyroglobuline; ThyroPerox, thyroperoxidase; un, undulated mouse mutant; WS, human Waardenburg syndrome; ?, putative interacting candidates; direct binding, target DNA is directly bound by Pax proteins (see text for details). "In this column, human syndromes or diseases are indicated in bold type before the colon, whereas mouse mutants are indicated in normal type before the colon. Affected structures are indicated after the colon.

and downregulation of Pax6 and provokes hypertrophia of the optic stalk and reduction of pigment epithelium and neural retina $\left[37^{\bullet \bullet}, 38\right]$. Pax 2 and $P a \times 6$ are thus crucial morphoregulators of the eye and are both under the regulation of ventralizing agents.

In the spinal cord, transplantation experiments in the chick indicate that the expression of $\mathrm{Pax} 3, \mathrm{Pax} 7$ and $\mathrm{Pax} 6$ is regulated by the notochord via a secretion of Shh and probably also by the roof plate and overlaying ectoderm, possibly via a secretion of bone morphogenetic proteins (BMPs) 4 and 7 [39,40]. Pax3, Pax6 and Pax 7 are expressed prior to neural differentiation in mitotically active cells, as opposed to Pax2, Pax5 and Pax 8 which are not expressed at this time. It has been reported that ectopic expression of $\operatorname{Pax}_{3}$ in the entire spinal cord of the mouse, using the Hoxb4 enhancer, does not confer dorsal identities as expected but instead leads to lack of the floor plate in the affected areas of the spinal cord of the transgenic animals [41]. Pax genes may thus be important regulators of the dorsoventral patterning of the spinal cord.

The Pax3 gene is inactivated by deletions or point mutations in various murine splotch or human Waardenburg syndrome semidominant alleles. Splotch mutants exhibit spina bifida, exencephaly, and neural-cress and limb-muscle defects $[8,9,42]$. Recent studies of splotch delayed, which produces a milder phenotype than other splotch alleles, revealed normal neuronal differentiation in dorsal and ventral regions of the affected neural tube 
[43]. Similarly, $P a x 7-1-$ mice do not show any obvious neural tube defect [44*]. Functional redundancy between $P a \times 3$ and $P a x 7$ could thus be responsible for the lack of abnormal neuronal differentiation phenotype in these mutants.

The Drosophila gooseberry (gsb) locus codes for two linked and structurally related genes, gsb-proximal and gsb-distal, which are homologues of the $\operatorname{Pax} 3$ and $P a x 7$ genes (for review, see [45]). Experiments in which Drosophila embryos carried a deletion removing both gsb transcripts or in which embryos ectopically expressed only one of gsb-distal and gsb-proximal clearly indicate that Gsb specifies row five neuroblasts $\left[46^{\bullet}, 47\right]$. Pax 3 and Pax7 may also specify neuronal identity in the spinal cord, and only double mutations of boch Pax genes may give us a definitive answer about their respective functions.

\section{Pax genes in organogenesis}

Pax genes are also expressed outside the central nervous system during organogenesis: $P a x l$ is expressed in thymus, Paxz and Pax8 in kidney, Pax8 in thyroid, Pax6 in pancreas and eye, and Paxt in pancreas ([14,24,48,49]; B Sosa-Pineda, P Gruss, unpublished data). Mutation of the Pax 1 gene in undulated mice leads to reduced thymus size and affects the maturation of the thymocytes [49]. Accordingly, Paxl seems to be required in thymus epithelium differentiation and hence influences $\mathrm{T}$-cell maturation [49]

Krd (kidney and retinal defects) mice with a deletion of a chromosomal segment that includes the Pax2 locus have kidney defects [50]. Kidney hypoplasia has been associated with heterozygosity of a human $P A X 2$ point mutation [15]. Experiments using antisense oligonucleotides to Pax2 in kidney organ culture, and inactivation of Pax2 by homologous recombination, demonstrate that this gene is essential for the development of the kidney epithelial components that are derived from the intermediate mesoderm $\left[51,52^{\bullet}\right]$.

Pax $8^{-1-}$ mice suffer from a thyroid defect (A Mansouri, P Gruss, unpublished data). Pax4-1- mice suffer from a pancreas defect (B Sosa-Pineda, P Gruss, unpublished data).

Targeted ectopic expression of cDNA encoding Drosophila eyeless or its murine homologue, Pax6, induces morphologically normal eyes in the wings, legs and antennae, demonstrating that eyeless is the master control gene for eye morphogenesis in Drosophila [53*54]. Analysis of homozygous sey mice, and studies of chimeric mouse embryos composed of wild-type and sey-mutant cells, indicates that Pax6 acts directly and in a cell-autonomous manner in the optic cup and lens, and is essential for lens and nasal-placode specification from surface ectoderm $\left[55,56^{\bullet}\right]$.
Pax proteins are thus crucial regulators of organogenesis in thymus, kidney, thyroid, pancreas and eye.

\section{Pax genes in cell differentiation}

Analysis of undulated mice demonstrates that Pax1 is essential for the condensation of the mesenchymal sclerotome cells and for the initiation of chondrogenesis [57]. The effect of Pax1 on sclerotome differentiation is regulated by the notochord via secretion of Shh $\left[58,5^{\circ}\right]$. Inactivation by gene targeting demonstrates that Pax5 is essential for early B-cell differentiation [35]. The limb muscles, whose prccursors express $\operatorname{Pax} 3$, are specifically disturbed in splotch mice [42]. Additionally, neural-crest derivatives, such as Schwann cells or melanocytes, are also affected in splotch mice [60-62]. In vitro experiments indicate that Pax3 is exclusively expressed in differentiating and nonmyelinating Schwann cells (see [63]). Accordingly, Pax3 in involved in the migration, differentiation and possibly the proliferation of the neural-crest cells and myoblasts. Also, Pax7 has been shown to play a role in cephalic neural crest specification, differentiation and/or proliferation $\left[44^{\circ}\right]$.

\section{Pax genes, cell proliferation and oncogenesis}

Overexpression of $P a x$ genes can transform fibroblasts into tumours in nude mice [18]. Similarly, the expression of $P A X 2$ and the paralogous gene $P A X 8$ are abnormally upregulated in Wilm's tumour, a paediatric renal carcinoma of mesenchymal origin $[64,65]$.

Translocations of human $P A X 3$ or $P A X 7$ result in the expression of a PAX-forkhead fusion protcin carrying the intact DNA-binding domains of the PAX3 or PAX7 molecules that are probably responsible for the generation of rhabdomyosarcoma $[17,66]$. In the case of the PAX3-forkhead fusion, the molecule produced is a more efficient transcription factor than PAX3 itself and would be expressed under the normal $P A X 3$ promoter [67]. It has not, however, been directly demonstrated that the fusion protein is driven by the $P A X$ promoter.

Deregulation of PAX5 expression has been reported in humans in malignant astrocytomas [68] and medulloblastomas [69]. In addition, the Pax5 promoter is modified in large-cell lymphomas by insertion of the potent $E \mu$ enhancer of the $\operatorname{IgH}$ gene [70]. It is not clear how Pax 5 is acting in these tumours but it may be involved in regulating cell proliferation, as in vitro experiments indicate that $\operatorname{Pax} 5$ may regulate proliferation in $\mathrm{B}$ cells [71].

Thus, the overexpression of Pax genes in tissues in which they are normally expressed may lead to tumorigenesis, suggesting that doses of Pax proteins are critical for their normal function. 


\section{Pax protein target genes}

Little is known about Pax target genes. However, in vitro protein-DNA binding assays and in vivo expression analysis indicate that a 1.0 kilobase fragment of the $E n 2$ enhancer contains binding sites for Pax2, Pax5 and Pax8 [72*]. Mutation of these binding sites disrupts initiation and maintenance of expression of the $\beta$-galactosidase reporter gene in the midbrain-hindbrain boundary of transgenic mice $\left[72^{\circ}\right]$.

Pax3 and the tyrosine kinase receptor for hepatocyte growth factor/scatter factor that is encoded by the c-met proto-oncogene are expressed in the lateral dermomyotome, that is, the progenitors of limb muscle [73]. Splotch mice display defects in neural-crest derivatives, failure of neural-tube closure and lack of limb muscles $[8,9,42]$. Splotch and c-met- ${ }^{-}$mice exhibit the same phenotype in the limb. Furthermore, c-met expression is greatly reduced in the dermomyotome of splotch embryos. In addition, Pax 3 directly activates c-met expression by binding to the c-met promoter, thus demonstrating that $\mathrm{c}-$ met is a target gene of Pax3 $\left[74^{\bullet}, 75\right]$.

Similarly, Pax5 was identified as a B cell specific transcription factor that regulates the expression of the CD19 gene which encodes a surface protein [76]. In addition, Pax8, which is expressed in the thyroid, binds to the promoter, and regulates the expression, of the thyroperoxidase and thyroglobuline genes [77].

In vitro experiments also show that $\mathrm{Pax} 5$ can directly inhibit transcription of the p53 gene by binding to the untranslated first exon, and could thereby parricipate in tumorigenesis [78].

\section{Conclusions}

Pax gene mutants are powerful tools for the study of Pax gene function. Nevertheless, functional redundancy between related members, alternative splicing and complex promoters complicate the analysis. Consequently, knockout mucants are grearly needed to study the effect of defined mutations. New techniques using conditional knockouts and knockins may be used to specifically inactivate the Pax gene of interest in a selected tissue at a defined time.

Pax protein doses play a crucial role in proper function of the proteins. The ectopic expression of Pax genes in transgenic mice may therefore give new insights into the mechanism of action of Pax proteins.

The possible regulation of cell adhesion by Pax proteins could explain some of the mutant phenorypes. In this context, in vitro approaches will most probably contribute to the functional analysis of the Pax genes.

\section{Acknowledgements}

We are grateful to Anastasia Stoykova and Beatriz Sosa-Pineda for communication of unpublished data. We also thank Jens Krull for his excellent technical assistance and Kenneth Ewan for critical reading of the manuscript. We would also like to thank Amanda Tromans for her fruitful comments and suggestions. This work was supported by the Max-Planck Society and the Leibniz Program. M Hallonet is a recipient of a Training and Mobility of Rescarchers grant from the European Community Council.

\section{References and recommended reading}

Papers of particular interest, published within the annual period of review, have been highlighted as:

- of special interest

- of outstanding interest

1. Bopp D, Burri M, Baumgartner S, Frigerio G, Noll M: Conservation of a large protein domain in the segmentation gene paired and in functionally related genes of Drosophila. Cell 1986, 47:1033-1040.

2. Deutsch U, Dressler GR, Gruss P: Pax1, a member of a paired box homologous murine gene family, is expressed in segmented structures during development. Cel/ 1988 , 53:617-625.

3. Mansouri A, Stoykova A, Gruss P: Pax genes in development. $J$ Cell Sci 1994, Suppl 1B:35-42.

4. Gruss P, Walther C: Pax in development Celf 1992 69:719-722.

5. Chalepakis $G$, Fritsch R, Fickenscher $H$, Deutsch $U$, Goulding $M$, Gruss P: The molecular basis of the undulated/Pax-1 mutation. Cell 1991, 66:873-884.

6. Czerny T, Schaffner G, Busslinger M: DNA sequence recognition by Pax proteins: bipartite structure of the paired domain and its binding site. Genes Dev 1993, 7:2048-2061.

7. Balling $R$, Deuisch $U$, Gruss P: Undulated, a mutation affecting the development of the mouse skeleton, has a point mutation in the paired box of Pax-1. Cell 1988, 55:531-535.

8. Epstein DJ, Vekemans M, Gros P: splotch ( $\left.\mathrm{Sp}^{2 H}\right)$, a mutation affecting development of the mouse neural tube, shows a deletion within the paired homeodomain of Pax-3. Cell 1991. 67:767-774.

9. Tassabehji $M$, Read AP, Newton VE, Patton $M$, Gruss P, Harris R, Strachan T: Mutations in the PAX3 gene causing Waardenburg syndrome type 1 and type 2. Nat Genet 1993, 3:26-30.

10. Walther $C$ Gruss $P$ : Pex-6, a murine paired box gene, is expressed in the developing CNS. Development 1991. 113:1435-1449.

11. Hill RE, Favor \&, Hogan BLM, Ton CCT, Saunders GF, Hanson IM, Prosser J. Jordan T, Hastie ND, Van Heyningen V: Mouse small eye results from mutations in a paired-like homeoboxcontaining gene. Nature 1991, 354:522-525.

12. Fujiwara M, Uchida T, Osumi-Yamashita N, Eto $K$ : Uchida rat ( $r$ Sey): a new mutant rat with craniofacial abnormalities resembling those of the mouse Sey mutant. Differentiation 1994, 57:31-38.

13. Jordan T, Hanson I, Zaletayev D, Hodgson S, Prosser J, Seawright $A$, Hastie $N$, Van Heyningen $V$ : The human PAX6 gene is mutated in two patients with aniridia. Nat Genet 1992, 1:328-332.

14. Dressler GR, Deutsch U, Chowdhury K, Nornes HO, Gruss P: Pax2, a new murine paired-box-containing gene and its expression in the developing excretory system. Development 1990, 109:787-795.

15. Sanyanusin P, Schimmenti LA, McNoe LA, Ward TA, Pierpont MEM, Sullivan MJ, Dobyns WB, Eccles MR: Mutation of the PAX2 gene in a family with optic nerve colobomas, renal anomalies and vesicoureteral reflux. Nat Genet 1995, 9:358-363.

16. Bennicelli JL, Edwards RH, Barr FG: Mechanism for transcriptional gain of function resulting from chromosomal translocation in alveolar rhabdomyosarcoma. Proc Natl Acad Sci USA 1996, 93:5455-5459. 
17. Davis RJ, DCruz CM, Lovell MA, Biegel JA, Barr FG: Fusion of $P A X 7$ to $F K H R$ by the variant $t(1 ; 13)(p 36 ; q 14)$ translocation in alveolar rhabdomyosarcoma. Cancer Res 1994, 54:2869-2872.

18. Maulbecker CC, Gruss P: The oncogenic potential of Pax genes. $E M B O$ J 1993, 12:2361-2367.

19. Stoykova A, Gruss P: Roles of Pax-genes in developing and adult brain as suggested by expression patterns. J Neurosci $1994,14: 1395-1412$

20. Goulding MD, Chalepkis $G$, Deutsch $U$, Erselius JR, Gruss $P$. Pax-3, a novel murine DNA binding protein expressed during early neurogenesis. EMBO J 1991, 10:1135-1147.

21. Jostes B, Walther $C$, Gruss $P$ : The murine paired box gene, Pax7, is expressed specifically during the development of the nervous and muscular system. Mech Dev 1991, 33:27-38.

22. Asano $M$, Gruss $P$ : Pax-5 is expressed at the midbrain-hindbrain boundary during mouse development. Mech Dev 1992, 33:27-38.

23. Nornes HO, Dressler GR, Knapik EW, Deutsch U, Gruss P: Spatially and temporally restricted expression of Pax2 during murine neurogenesis. Development 1990, 109:797-809.

24. Plachov D, Chowdhury $K$, Walther $C$, Simon $D$, Guenet J-L Gruss $P: P a x 8$, a murine paired box gene expressed in the developing excretory system and thyroid gland. Development 1990, 110:643-651.

25. Puelles L, Rubenstein JLR: Expression patterns of homeobox and other putative regulatory genes in the embryonic mouse forebrain suggests a neuromeric organization. Trends Neurosci 1993, 16:472-479.

26. Macdonald $R, X u Q$, Barth KA, Mikkola I, Holder N, Fjose A, Krauss S, Wilson SW: Regulatory gene expression boundaries demarcate sites of neuronal differentiation in the embryonic zebrafish forebrain. Neuron 1994, 13:1039-1053.

27. Hanson $M, V a n$ Heyningen $V$ : Pax6: more than meets the eye. Trends Genet 1995, 11:268-272.

28. Stoykova A, Walther $C$, Fritsch $R$, Gruss P: Forebrain patterning -. defects in Small eye mutant mice. Development 1996, in press. This careful and exhaustive analysis of the small eye mutant mouse with various molecular markers brings new insights into mechanisms of brain patterning in relation to the prosomeric model and the role of Pax 6 in this context.

29. Vincent S, Turque N, Plaza S, Dhellemmes P, Hladky JP, Assaker R, Ruchoux MM, Saule S: Differential expression between Pax6 and En proteins in medulloblastoma. Int \& Oncol 1996, 8:901-910.

30. Alvarado-Mallart R-M: Fate and potentialities of the avian mesencephalic/metencephalic neuroepithelium. J Neurobio/ 1993, 24:1341-1355.

31. Crossley PH, Martinez S, Martin GR: Midbrain development -. induced by FGF8 in the chick embryo. Nature 1996, 380:66-68. Implantation of FGFB-coated beads into the forebrain mimics the effect of midbrain-hindbrain tissue grafts in inducing the expression of En2 and Wnt1 and the differentiation of mesencephalic-like structures. Accordingly, FGFB is a major regulator of the formation of this brain territory, which is where it is normally expressed.

32. Crossley PH, Martin GR: The mouse FGF8 gene encodes a family of polypeptides and is expressed in regions that direct outgrowth and patterning in the developing embryo. Development 1995, 121:439-451.

33. Joyner AL: Engrailed, Wht and Pax genes regulate

-. midbrain-hindbrain development. Trends Genet 1996 12:15-20.

This review compares the phenotypes produced by mutations in Wnt1 and En1 with those produced by mutations in $E_{n} 2$ and Pax5. The review also looks at the FGF8 expression pattern. The author proposes that a cascade of molecular interactions patterns the central nervous system at the midbrain-hindbrain boundary level.

34. Krauss $S$, Maden M, Holder N, Wilson SW: Zebrafish pax[b] is involved in the formation of the midbrain-hindbrain boundary. Nature $1992,360: 87-89$

35. Urbanek $P$, Wang $Z Q$, Fetka 1 , Wagner $E F$, Busslinger $M$ : Complete block of early $B$ cell differentiation and altered patterning of the posterior midbrain in mice lacking Pax5/BSAP. Cell 1994, 79:901-912.

36. Macdonald R, Wilson SW: Pax proteins and eye development Curr Opin Neurobiol 1996, 6:49-56.
37. MacDonald R, Barth KA, Xu Q, Holder N, Mikkola I, Wilson SW: -. Midline signalling is required for Pax gene regulation and patterning of the eyes. Development 1995, 121:3267-3278. Pax2 and Pax6 gene expressions were analyzed in zebrafish cyclop mutants in which the ventral axial mesoderm is affected, and when Shh was overexpressed in the developing wild-type central nervous system. A midline signalling molecule, possibly Shh, induces Pax2 expression and inhibits the expression of the Pax6 gene (see [38]).

38. Ekker SC, Ungar AR, Greenstein $P$, Von Kessler DP, Porter JA Moon RT, Beachy PA: Patterning activities of vertebrate hedgehog proteins in the developing eye and brain. Curr Biol 1995, 5:944-955.

39. Goulding MD, Lumsden A, Gruss P: Signals from the notochord and floor plate regulate the region-specific expression of two Pax genes in the developing spinal cord. Development 1993. 117:1001-1016.

40. Liem KF, Remml G, Roelink H, Jessel TM: Dorsal differentiation of neural plate cells induced by BMP-mediated signals from epidermal ectoderm. Cell 1995, 82:969-979.

41. Tremblay $P_{1}$ Pituello $F_{1}$ Gruss $P$ : Inhibition of floor plate differentiation by Pax3: evidence from ectopic expression in transgenic mice. Development 1996, 122:2555-2567.

42. Franz $T$, Kothary $R$, Surani MAH, Grim M: The Splotch mutation interferes with muscle development in the limbs. Anat Embryol 1993, 187:153-160.

43. Keller-Peck CR, Mullen RJ: Patterns of neuronal differentiation in neural tube mutant mice: curly tail and Pax3 splotch-delayed. $J$ Como Neur 1996, 368:516-526.

44. Mansouri A, Stoykova A, Torres M, Gruss P: Dysgenesis of - cephalic neural crest derivatives in $P_{a \times} 7^{-1-}$ mutant mice. Development 1996, 122:831-838.

Pax7-knockout mice produced by homologous recombination carry defects in facial neural crest derivatives. This study leads to the conclusion that Pax7 is essential or very crucial for the development of only a restricted population of cephatic neural crests in which the gene is expressed. Functional redundancy between Pax 3 and $P a x 7$ is discussed in the paper.

45. Noll M: Evolution and role of Pax genes. Curr Opin Genet Dev 1993, 3:595-605.

46. Skeath JB, Zhang $Y$, Holmgren $R$, Caroll SB, Doe CQ - Specification of neuroblast identity in the Drosophila embryonic central nervous system by gooseberry-distal. Nature 1995, 376:427-430.

This study demonstrates that lack of gooseberry-distal transforms row five neuroblasts, where it is normally expressed, into row three neuroblasts, one of the other four rows that are normally present in each Drosophila segment. Inversely, ubiquitous expression of the same gene generates the reciprocal transformation, thus demonstrating that gooseberry-dista/ is one of the prime candidates for controlling specific neuroblast identity.

47. Zhang $Y$, Ungar $A$, Fresquez $C$, Holmgren R: Ectopic expression of either the Drosophila gooseberny-distal or proximal gene causes alterations in the epidermis and central nervous system. Development 1994, 120:1151-1161.

48. Turque N, Plaza S, Radvanyi F, Carriere C. Saule S: PaxQNR/Pax-6, a paired box- and homeobox-containing gene expressed in neurons, is also expressed in pancreatic endocrine cells. Mol Endocrinol 1994, 8:929-938.

49. Wallin J, Eibel $H$, Neubüser A, Wilting J, Koseki H, Balling R: Pax1 is expressed during development of the thymus epithelium and is required for normal T-cell maturation. Development 1996, 122:23-30.

50. Keller SA, Jones JM, Boyle A, Barrow LL, Killen PD, Green DG, Kapousta NV, Hitchcock PF, Swank RT, Meisler MH: Kidney and retinal defects (Kro), a transgene induced mutation with a deletion of mouse chromosome 19 that includes the Pax2 locus. Genomics 1994, 23:309-320.

51. Rothenpieler UW, Dressler GR: Pax-2 is required for mesenchyme-to-epithelium conversion during kidney development Development 1993, 119:711-720.

52. Torres M, Gomez-Pardo E, Dressler GR, Gruss P: Pax-2 controls - multiple steps of urogenital development. Development 1995 , 121:4057-4065

Pax2-knockout mice lack kidneys, ureters and genital tracts. This study demonstrates that Pax2 is essential for the formation of kidney epithelium from the mesenchyme of the intermediate mesoderm (see also [51]).

53. Halder G, Callaerts P, Gehring WJ: Induction of ectopic eyes by

- targeted expression of the eyeless gene in Drosophila. Science $1995,267: 1788-1792$. 
Targeted ectopic expression of the Drosophila eyeless gene or of the mouse Pax6 gene in various imaginal disc primordia of the Drosophila embryo leads to induction of ectopic eye structures in the wings, legs and antennae. These results support the conclusion that eyeless and the related Pax6 are master control genes for eye morphogenesis.

54. Quiring R, Walldorf U, Kloter U, Gehring WJ : Homology of the eyeless gene of Drosophila to the small eye gene in mice and Aniridia in humans. Science 1994, 265:785-789.

55. Grindley JC, Davidson DR, Hill RE: The role of Pax-6 in eye and nasal development Development 1995, 121:1433-1442.

56. Quinn JC, West JD, Hill RE: Multiple function for Pax6 in mouse - eve and nasal development. Genes Dev 1996, 10:435-446. Using chimeras of sey mutant and wild-type cells, the authors observed that sey cells were excluded from lens and nasal epithelium in these chimeric animals, thus indicating that $P a x 6$ is required in a cell-autonomous manner for the formation of these structures. The authors also confirm that Pax6 is also necessary for the proper formation of the optic cup (see also [55]).

57. Wallin J, Wilting J, Koseki H, Fritsch R, Christ B, Balling R: The role of Pax-1 in axial skeleton development. Development 1994, 120:1 109-1121.

58. Ebensperger C, Wilting J, Brand-Saberi B, Mizutani Y, Christ B, Balling R, Koseki H: Pax-1, a regulator of sclerotome development is induced by notochord and floor plate signals in avian embryos. Anat Embryol 1995, 191:297-310.

59. Fan CM, Porter JA, Chiang C, Chang DT, Beachy PA, Tessier-

- Lavigne M: Long-range sclerotome induction by sonic hedgehog: direct role of the amino-terminal cleavage product and modulation by the cyclic AMP signaling pathway. Cell and modulation by

Culture systems of presomitic mesoderm explants were used to demonstrate that Shh induces the expression of Pax1. In addition, different levels of Pax 1 expression were induced by different concentrations of Shh. Inversely, the authors also report a repression of the expression of Pax3 in the Shh-treated explants.

60. Moase CE, Trasler DG: Delayed neural crest emigration from Sp and Spd mouse neural tube explants. Teratology 1990 , 42:171-182.

61. Franz $T$, Kothary $R$ : Characterization of the neural crest defect in Splotch $\left(\mathrm{Sp}{ }^{1 H}\right)$ mutant mice using a lac $Z$ transgene. Dev Brain Res 1993, 72:99-105.

62. Auerbach R: Analysis of the developmental effects of a lethal mutation in the house mouse. J Exp Zoo/ 1954, 127:305-329.

63. Kioussi C, Gruss P: Making of a Schwann. Trends Genet 1996, 12:84-86.

64. Poleev A, Fickenscher $H$, Mundlos $S$, Winterpacht A, Zabel $B$, Fidler A, Gruss P, Plachor D: PAXB, a humen paired box gene: isolation and expression in developing thyroid, kidney and Wilms' tumor. Development 1992, 116:611-623.

65. Dressler GR, Douglass EC: Pax-2 is a DNA-binding protein expressed in embryonic kidney and Wilms tumor. Proc Natl Acad Sci USA 1992, 89:1179-1183.

66. Shapiro DN, Sublett JE, Li B, Downing JR, Naeve CW: Fusion of PAX3 to a member of the forkhead family of transcription factors in human slveolar rhabdomyosarcoma. Cancer Res 1993, 53:5108-5112.

67. Bonnicelli JL, Edwards RH, Barr FG: Mechanism for transcriptional gain of function resulting from chromosomal translocation in alveolar rhabdomyosarcoma. Proc Natl Acad Sci USA 1996, 93:5455-5459.

68. Stuart ET, Kioussi C, Aguzzi A, Gruss P: Pax-5 expression correlates with the increasing malignancy in human astrocytomas. Clin Cancer Res 1994, 1:207-214.

69. Kozmik Z, Sure U, Rüedi D, Busslinger M, Aguzzi A: Deregulated expression of PAX-5 in medulloblastoma. Proc Nat/ Acad Sci USA 1995, 92:5709-5713.

70. Busslinger $M$, Klix $N$, PYeffer $P$, Graninger PG, Kozmik Z:

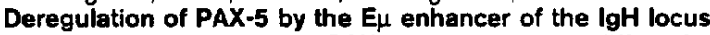
adjacent to two alternative PAX-5 promoters in a diffuse largecell lymphomas. Proc Natl Acad Sci USA 1996, 93:6129-6134.

71. Wakatsuki $Y W$, Neurath MF, Max EE, Strober $W$ : The $B$ cellspecific transcription factor BSAP regulates B cell proliferation. $J$ Exp Med 1994, 179:1099-1 108.

72. Song DL, Chelapakis G, Gruss $P$, Joyner AL: Two Pax binding - sites are required for early embryonic brain expression of an Engrailed-2 transgene. Development 1996, 122:627-635.

The En2 enhancer, which can direct $\beta$-galactosidase expression in the midbrain-hindbrain boundary of transgenic mice, has two binding sites for the Pax2, Pax5 and Pax8 proteins. Mutation or deletion of the two Pax5. binding sites abolishes the expression of lacz in this brain area of transgenic animals.

73. Ordahl CP, Le Douarin NM: Two myogenic lineages in the developing somite. Development 1992, 114:339-353.

74. Epstein JA, Shapiro DN, Cheng J, Lam PY, Maas RL: Pax3

- modulates expression of the c-met receptor during limb muscle development. Proc Natl Acad Sci USA 1996, 93:4213-4218

Binding assay experiments identified the Pax3-binding site on the human cmet promoter. Furthermore, cuture experiments demonstrated that Pax 3 can stimulate c-met expression. These results are consistent with the observation that c-met is downregulated in splotch mice (see also [75]).

75. Bladt F, Riethmacher D, Isenmann S, Aguzzi A, Birchmeier C Essential role for the $c$-met receptor in the migration of myogenic precursor cells in the limb bud. Nature 1995, 376:768-771.

76. Adams B, Dörfler P, Aguzzi A, Kozmik Z, Urbánek P, Maurer-Fogy I, Busslinger M: Pax-5 encodes the transcription factor BSAP and is expressed in B lymphocytes, the developing CNS, and adult testis. Genes Dev 1992, 6:1589-1607.

77. Zannini M, Francis-Lang $H$, Plachov D, Di Lauro R: Pax-8, a paired domain-containing protein, binds to a sequence overlapping the recognition site of a homeodomain and activates transcription from two thyroid-specific promoters. $\mathrm{Mol}$ Cell Biol 1992, 12:4230-4241.

78. Stuart ET, Haffner R, Oren M, Gruss P: Loss of p53 function through PAX-mediated transcriptional repression. EMBO I 1995, 14:5638-5645. 